УдК: $351: 331.83$

DOI: https://doi.org/10.32689/2617-

2224-2019-5(20)-109-123

Ковач Валерія Омелянівна,

кандидат технічних наук, заступник директора з наукової роботи, Навчально-науковий інститут неперервної освіти, Національного авіаційного університету, 03058, м. Київ, просп. Космонавта Комарова, 1, тел.: (044) 40672 10, е-таil: valeriiakovach@gmail.com

ORCID: 0000-0002-1014-8979

Ковач Валерия Емельяновна,

кандидат технических наук, заместитель директора по научной работе, Уиебно-научный институт непрерывного образования Национального авиащионного

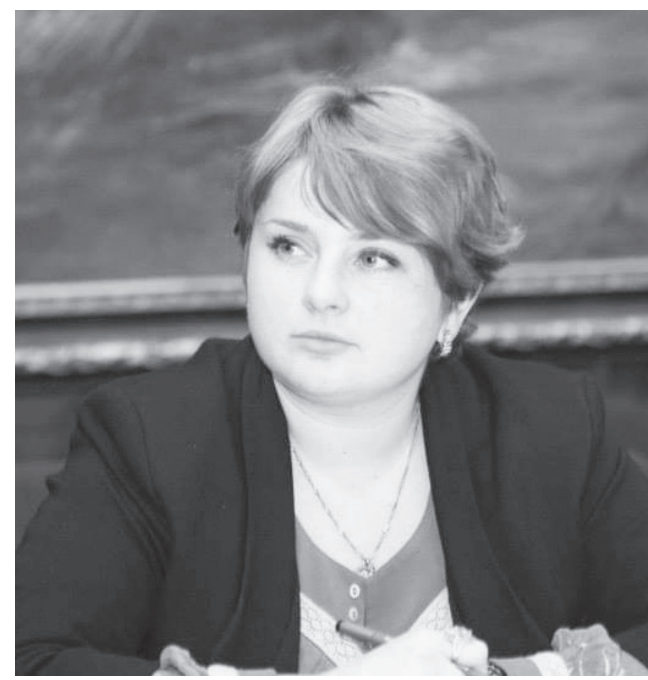
университета, 03058, г. Киев, просп. Космонавта Комарова, 1, тел.: (044) 40672 10, e-mail:valeriiakovach@gmail.com

ORCID: 0000-0002-1014-8979

Kovach Valeriia Omelianizna,

PhD in technical sciences, Deputy Director on scientific work Educational and Research Institute of Continuing Education National Aviation University, Prospekt Kosmonavta Komarova, 1, tel.: (044) 40672 10, e-mail:valeriiakovach@gmail.com

ORCID: 0000-0002-1014-8979

\title{
ПРОГНОЗУВАННЯ МЕХАНІЗМУ УПРАВЛІННЯ РИНКОМ ПРАЦІ
}

Анотація. Розглянуто складові механізму державного управління ринком праці України та сформовано комплексний механізм його державного регулювання. Проаналізовано сучасні управлінські технології та сучасна діяльність апарату управління на ринку праці. Показано важливість розвитку стратегії та методології у процесі кадрового управління. Розглянуто критерії урівноваження потреб ринку праці на національному та регіональному рівнях. Розкрито проблеми регіонального управління ринком праці, що призводять до створення “кадрового голоду”. Проаналізовано виконання програм дій управлінських інститутів щодо покращення умов управління ринком праці. Сформульовано кілька варіантів сценарного прогнозу розвитку ринку праці у зв'язку з кризовою нестабільністю соціально-економічної ситуації на регіональних ринках праці. Наведено блочний підхід прогнозу робочої сили. Виділені зразкові тенденції на регіональному рівні при розгляді співвідношення попиту і пропозиції на ринку праці. Проаналізовано 
поняття “безробітні”, “економічно активне населення” та “самозайняте населення”. Наведено розподіл економічно активного населення на групи. Показано підходи до протидії потенційному, частковому і реальному безробіттю. Розглянуто зміну місця проблем ринку праці в системі пріоритетів державної економічної політики та запропоновані варіанти перебудови структури управління. Проаналізовано варіанти підвищення громадського статусу працеринкових проблем. Обгрунтовано ознаки формування економічного агента відповідно до кон'юнктури ринку праці. Наведено основні елементи організаційно-управлінського механізму ринком праці та економіко-організаційні методи управління ринком. Доведено необхідність удосконалення системи моніторингу та прогнозування ринку праці. Запропоновано варіанти виходу з кризи у трудовій сфері України.

Ключові слова: прогнозування, державні механізми управління, ринок праці, кадрове управління, стратегія, економічний агент, працеринкова проблема.

\section{ПРОГНОЗИРОВАНИЕ МЕХАНИЗМА УПРАВЛЕНИЯ РЫНКОМ ТРУДА}

Аннотация. Рассмотрены составляющие механизма государственного управления рынком труда Украины и сформирован комплексный механизм его государственного регулирования. Проанализированы современные управленческие технологии и современная деятельность аппарата управления на рынке труда. Показана важность развития стратегии и методологии в процессе кадрового управления. Рассмотрены критерии уравновешивания потребностей рынка труда на национальном и региональном уровнях. Раскрыты проблемы регионального управления рынком труда, приводящие к созданию “кадрового голода”. Проанализировано выполнение программ действий управленческих институтов по улучшению условий управления рынком труда. Сформулировано несколько вариантов сценарного прогноза развития рынка труда в связи с кризисной нестабильностью социально-экономической ситуации на региональных рынках труда. Приведены блочный подход прогноза рабочей силы. Выделены образцовые тенденции на региональном уровне при рассмотрении соотношения спроса и предложения на рынке труда. Проанализировано понятие “безработные”, “экономически активное население" и “самозанятое население”. Приведено распределение экономически активного населения на группы. Показано подходы к противодействию потенциальному, частичной и реальной безработице. Рассмотрено изменение места проблем рынка труда в системе приоритетов государственной экономической политики и предложены варианты перестройки структуры управления. Проанализированы варианты повышения общественного статуса трудорынковых проблем. Обоснованы признаки формирования экономического агента в соответствии с рынком труда. Приведены основные элементы организационно-управленческого механизма рынком труда и экономико-организационные методы управления рынком. Доказана необ- 
ходимость совершенствования системы мониторинга и прогнозирования рынка труда. Предложены варианты выхода из кризиса в трудовой сфере в Украине.

Ключевые слова: прогнозирование, государственные механизмы управления, рынок труда, кадровое управление, стратегия, экономический агент, трудорынковая проблема.

\section{FORECASTING THE MECHANISM OF THE LABOR MARKET MANAGEMENT}

Abstract. The components of the mechanism of state management of the labor market of Ukraine are considered and a complex mechanism of its state regulation is formed. The modern management technologies and modern activity of the management apparatus in the labor market are analyzed. The importance of development of strategy and methodology in the process of personnel management is shown. The criteria for balancing labor market needs at national and regional levels are considered. The problems of regional management of the labor market, which lead to the creation of "staff hunger", are revealed. The implementation of the management programs of the management institutes on improving the conditions of labor market management is analyzed. Several variants of the scenario forecast of labor market development are formulated in connection with the crisis of instability of the socio-economic situation in the regional labor markets. The block approach of workforce forecasting is presented. Model tendencies at the regional level are highlighted when considering the labor market supply and demand ratio. The concepts of "unemployed", "economically active population" and "self-employed population" are analyzed. The distribution of economically active population into groups is given. Approaches to counteracting potential, partial and real unemployment are shown. The change of place of labor market problems in the system of priorities of the state economic policy is considered and the options of restructuring of the management structure are offered. Options for raising the public status of problems of concern have been analyzed. Signs of formation of economic agent in accordance with the situation of the labor market are substantiated. The basic elements of the organizational and managerial mechanism of the labor market and the economic and organizational methods of market management are given. The necessity of improving the system of monitoring and forecasting of the labor market is substantiated. Proposed ways out of the crisis in the labor sphere in Ukraine.

Keywords: forecasting, state control mechanisms, labor market, personnel management, strategy, economic agent, labor-market problem.

Постановка проблеми. Полі- успішність виконання управлінтика комплексного реформування ських рішень, зокрема, на ринку прасуспільства і економіки в Україні, ці висуваються істотно нові вимоги 
до керівників різних рівнів і сфер адміністративно-господарської діяльності. Важливу роль в еволюції національної економічної системи відіграє ринок праці. Недостатній рівень оплати праці в Україні, недостатньо розвинені механізми формування ринкової вартості вітчизняної робочої сили та значні розбіжності в оплаті праці у різних регіонах України призводить до непропорційного розподілу економічно активного населення та міграції робочої сили [1]. Рух України до ЄС передбачає підвищення рівня ефективності національного ринку праці, запровадження інновацій як на ринку праці, так і в освітній сфері [2]. Досягнути поставлені завдання буде можливо лише правильно сформувавши державні механізми прогнозування управління ринком праці.

Аналіз останніх досліджень та публікацій. Загальнометодологічні засади функціонування й розвитку ринку праці, об'єктивну необхідність втручання держави в регулювання трудової сфери обгрунтовано у працях таких вітчизняних вчених, як: В. Онікієнко, 3. П. Бараник, C. I. Бандур, Б. М. Данилишин, Е. М. Лібанова, Л. С. Лісогор, В. Петюх, Н. О. Парфенцева, С. І. Пірожков, В. Г. Саріогло, А. В. Хмелюк, М. Г. Чумаченко та ін. Проте існує необхідність у дослідженні національного та регіональних ринків праці для виявлення основних тенденцій та безпосереднього прогнозування механізмів управління таким ринком.

Мета статті полягає у виявленні тенденцій розвитку основних показників функціонування національ- ного та регіонального ринків праці України, а також в обгрунтуванні формування комплексного прогнозного механізму управління ринком праці України.

Виклад основного матеріалу дослідження. Згідно з “ефектом Едіпа", маючи прогноз негативного явища $\mathrm{i}$ знаючи його причини, можна вжити заходи, щоб воно не здійснилося, впливаючи на відповідні причини. Прогнозування при паралельному концептуванні управління ринком праці [3] служить основою для організації роботи із забезпечення балансу зайнятості працездатного населення і наявних робочих місць, оскільки 3 певною достовірністю дозволяє оцінити:

1) ситуацію, що складається, зі співвідношенням попиту і пропозиції економічних агентів;

2) можливу чисельність незайнятого населення, яке може звернутися за сприянням у працевлаштуванні в не лише державні органи, а також чисельність вакантних і новостворюваних незайнятих робочих місць;

3) розподіл робочої сили, що виявилася на ринку праці (можливі обсяги перепідготовки працівників, що вивільняються, і незайнятого населення, потенційну чисельність безробітних).

Перехід на результативні управлінські технології потребує від менеджерів різних рівнів і пластів нових теоретичних знань і практичних навичок, уміння співпрацювати в гнучких “командах", інтегрувати фінансово-статистичну інформацію, враховувати реакцію громадськості.

Сучасна діяльність апарату управління на ринку праці, що фор- 
мується, недостатньо відкрита, тому малоефективна. Для цього необхідно впроваджувати і поширювати ментальні особливі якості управлінців і сфери компетентності керівників державних установ (табл. 1).

Виникає новий тип менеджерів зі специфічними прогресивними соціально-виробничими характеристиками (рідкісними і дефіцитними в регіоні), що формується новими галузями і ринковою конкуренцією, яка загострилася. Посилюється незалежність найманого менеджера-професіонала від капіталу, що найняв його. Автономний статус управлінця [4] охороняє процес прийняття економічного рішення від неграмотних і безвідповідальних втручань з боку акціонерів підприємств, профспілок, політичних діячів [5].

В економічно розвинених країнах, говорячи про управління працею мають на увазі саме “людські ресурси” і розглядають їх системно: вкладений капітал, матеріальні ресурси, технології. Ефективне управління сьогодні можливо завдяки передусім високорозвиненим інформаційним технологіям, а більше ніж гроші, чин- ник часу раціоналізував управління процесом ринку праці. Тільки добре організована і мотивована праця може дати стиглі плоди [6].

У сучасних умовах, коли відбуваються щогодинні, багатосторонні, багатофакторні зміни, класичне управління на основі характерно кадрових структур може лише частково задовольнити потреби працедавця, запити управління людськими ресурсами.

В процесі кадрового управління працедавець повинен розвивати стратегію і методологію, засновану на управлінні інформаційним потоком ведення справ, впровадженням програмного продукту в конкретні умови. Метою аналізу планування повинно стати відносне урівноваження потреб ринку праці (як i ринків товарів, послуг, фінансів i так далі) і можливостей ресурсів. Відповідні програми дозволять на оперативному рівні менеджменту синхронізувати виконання планових робіт і фактичної діяльності, а також збалансувати потужності кожного ресурсу, і особливо кадрів [7-9].

Усвідомлюючи значущість кожного працівника для підприємства,

Таблиця 1

Ментальні сфери компетентності управління

\begin{tabular}{|l|l|l|l|}
\hline $\begin{array}{l}\text { Управління } \\
\text { конфліктами }\end{array}$ & Творче мислення & $\begin{array}{l}\text { Орієнтація } \\
\text { користувачів }\end{array}$ & $\begin{array}{l}\text { Фінансове } \\
\text { управління }\end{array}$ \\
\hline $\begin{array}{l}\text { Обізнаність } \\
\text { обо зовнішню } \\
\text { обстановку }\end{array}$ & Рішучість & Гнучкість & $\begin{array}{l}\text { Управління } \\
\text { людськими } \\
\text { ресурсами }\end{array}$ \\
\hline $\begin{array}{l}\text { Управління } \\
\text { різноманітною } \\
\text { робочою силою }\end{array}$ & $\begin{array}{l}\text { Навички } \\
\text { міжособових } \\
\text { стосунків }\end{array}$ & $\begin{array}{l}\text { Техніко-технологічна } \\
\text { компетентність }\end{array}$ & $\begin{array}{l}\text { Управлінський } \\
\text { контроль } \\
\text { і інтеграція }\end{array}$ \\
\hline $\begin{array}{l}\text { Вплив і ведення } \\
\text { переговорів }\end{array}$ & Планування і оцінка & $\begin{array}{l}\text { Усні і письмові } \\
\text { комунікації }\end{array}$ & $\begin{array}{l}\text { Формування } \\
\text { команди }\end{array}$ \\
\hline Самоврядування & Лідерство & Загальне бачення & Рішення проблем \\
\hline
\end{tabular}


сучасний працедавець, виробляючи стратегію управління персоналом, разом з професійним підбором кадрів відводить велику роль трудовим відносинами, організації обліку праці, просуванню по роботі, методам і стандартам оплати праці, формальним і неформальним зв'язкам. Така система повинна гнучко сприяти структуризації без порушення цілісності, бути надійною, здатною відновлюватися при організаційно-технологічних збоях, а також забезпечувати ефективний захист від несанкціонованого доступу до даних (за розрахунком зарплати, з обліку кадрів, за штатним розкладом).

Доля кадрового підрозділу, про який не йдеться практично в жодному рекламному проспекті торговельного або промислового підприємства, залишатися в тіні зі своїми внутрішніми турботами (у тому числі з роботою із координації та кадрового моніторингу) [10]. Але практика підтверджує, що з досвідченими кадровиками повинні працювати люди, які пройшли школу бізнесу, щоб при підтримці іміджу підприємства простежувати вимоги до набору персоналу.

Крім замовлення на цільову рекламу, участі в загальнонаціональних рекламних кампаніях повинні активізуватися можливості місцевої преси, радіо і телебачення, даватися оголошення, постійно зондуватися регіональні ринки праці. У кадровій політиці, як з будівництвом будинку: “чим міцніше фундамент, тим довше стоїть зданий в експлуатацію об’єкт” [11].

Причини загострення проблем регіонального управління криються, по-перше, в односторонньому вдосконаленні економічної бази уразливих промислових підприємств, створених як ланки великих технологічних комплексів з одним споживачем їх продукції - державою); по-друге, деформаціях соціально-демографічної структури (колишне планування розміщення продуктивних сил зумовило економічну базу, що має, зокрема, низькоеластичний ресурс - персонал наукомістких виробництв у високоіндустріальних районах); по-третє, низькому рівні міської інфраструктури (невідповідність розміщенню (кількості) і потребам (якості) соціально-побутового середовища.

Прогноз ринку праці $є$ базою для визначення обсягу коштів, необхідних для виконання програм дій управлінських інститутів ринку праці, а також дозволяє визначити пріоритети регіональної політики на цьому ринку на прогнозований період і розробити заходи, спрямовані на запобігання масовому безробіттю і забезпечення соціальних гарантій громадян у сфері їх зайнятості. Позадержавне фінансування політики на ринку праці може складатися як на основі атрибутивної (розподільної), так і алокаційної (збиральної ззовні) точок зору [12; 13$]$.

Найважливіший методологічний принцип прогнозування - принцип поліваріантності (пасивний прогноз (на аналізі поточних тенденцій розгортання процесу) і активний прогноз (цілеспрямована діяльність 3 підвищення трудової активності працездатних громадян на ринку праці). У зв'язку з кризовою нестабільністю соціально-економічної ситуації мо- 
жуть бути сформульовані 2-3 варіанти сценарного прогнозу: 1) відбиваючий (зміна обсягів виробництва (мінімальний), що склалася); 2) що передбачає дещо вищі темпи зміни обсягів виробництва (середній); 3) заснований на можливих значних змінах обсягів виробництва (максимальний). Показники зміни обсягів виробництва, що закладаються в різні варіанта прогнозу, визначаються на підставі даних місцевих економічних і управлінських органів. На основі третього варіанту прогнозу може бути сформований окремий розділ програми виходу з кризи, що припускає появу кризово нестабільних з точки зору зайнятості працездатного населення територій (міст, районів), секторів економіки, окремих підприємств, соціально-демографічних груп населення.

Нині (при різко контрастному перевищенні на ринку праці пропозиції робочої сили над попитом на неї з боку власників робочих місць) розрахунки слід здійснювати у фізичних особах, а не в середньорічному численні. У перспективі, коли ситуація на ринку праці стане стабільною, доцільніше буде перейти до його розрахунку в середньорічному обчисленні. При розрахунках необхідно враховувати національні і демографічні особливості, специфіку соціальноекономічного розвитку територій, міру поширення тих або інших форм ринкових відносин. Прогноз ринку робочої сили може складатися 3 4-х блоків: 1 блок - пропозиція робочої сили, що дозволяє визначити чисельність різних категорій громадян, які пропонують послуги робочої сили на ринку праці, що формується;
II блок - попит на робочу силу, що дозволяе оцінити потребу виробництва в працівниках на основі даних; III блок - співвідношення попиту i пропозиції, що відбиває міру напруженості на ринку праці; IV блок - розподіл робочої сили, що надає можливість оцінити чисельність громадян, які працевлаштовуються самостійно, тобто минувши службу зайнятості (у т. ч. недержавні посередницькі організації), які звертаються за сприянням у працевлаштуванні в службу зайнятості, а також визначити можливу чисельність працевлаштовуваних цією службою громадян, осіб, яким потрібно буде пройти перепідготовку і безробітних.

У цілому по регіону, при розгляді співвідношення попиту і пропозиції, можна виокремити наступні зразкові тенденції:

a) стійке негативне сальдо в цілому по регіону при різній мірі відхилення в той або іншій бік за окремими соціально-демографічними i професійними групами;

б) тимчасовий дисбаланс попиту і пропозиції в цілому по регіону і за основними соціально-демографічними i професійними групами, зумовлений, передусім порушенням господарських зв'язків, договірних зобов'язань і фінансовими труднощами у зв'язку з неплатоспроможністю суміжників або браком готівкової грошової маси.

Не дивлячись на значну складність, украй важливо чітко визначити, у яких секторах економіки, за якими соціально-демографічними і професійними групами зниження попиту має стійкий, довгочасний характер, де цей процес набуває ко- 
роткострокового кон'юнктурного характеру, а також, де за певних умов, можливе пожвавлення і позитивна динаміка попиту на робочу силу. При формуванні на основі повномасштабних розрахунків регіонального ринку праці, програмних документів із забезпечення зайнятості населення необхідно передбачати не лише пасивну фіксацію співвідношення попиту і пропозиції, але i передбачати, з урахуванням місцевих можливостей, міри активного впливу на динаміку цих показників.

3 числа безробітних необхідно визначити:

1) чисельність осіб, які отримують допомогу з безробіття, що розраховується, виходячи з фактичних даних, коригованих 3 урахуванням можливої чисельності осіб, яким виплата допомоги може бути відкладена (наприклад, звільнені за прогул і за інші порушення трудової діяльності), а також осіб, у яких термін отримання допомоги може бути понад 12 місяців;

2) чисельність осіб, які беруть участь в оплачуваних громадських роботах, величина якої залежить від чисельності безробітних громадян, чисельності безробітних, які не одержують допомогу з безробіття, а також регіональних особливостей економічного розвитку (можливість організації сезонних громадських робіт, цілорічних, у сільському і лісовому господарствах, комунальній i дорожній службах і т. д.).

В економічно активне населення входять усі осіби обох статей, які пропонують робочу силу для виробництва економічних благ i послуг протягом певного звітного періоду.
Зазвичай активне населення охоплює всіх осіб старше певного віку, які більше число тижнів або днів протягом тривалого періоду (наприклад, попередніх 12 місяців або попереднього календарного року) були зайняті або безробітними. Робоча сила, або населення, активне в даний момент, охоплює всіх осіб, які задовольняють вимогам для віднесення до зайнятих або безробітних. Зайнятих слід розділяти на найнятих робітників і зайнятих на власному підприємстві (самозайнятих). Перших треба підрозділити на тих, які “працюють за зарплату або оплату грошима або натурою” і на тих, які "мають робоче місце, але тимчасово не працюють”. Для останніх формальний зв'язок $з$ робочим місцем варто визначати з урахуванням національних особливостей, а також:

а) отримання заробітної або оплати;

б) завірення в можливості повернутися на роботу після того, як зміняться певні обставини, або наявність узгодженої дати повернення на работу;

в) закінчення терміну відсутності на роботі, яким, у певних випадках, може бути той термін, протягом якого працівник може отримувати юмпенсаційні виплати без зобов'язання погоджуватися на іншу роботу.

Самозайняті - це “працюючі" особи, які протягом досліджуваного періоду виконували роботу для отримання прибутку або блага сім’і, грошима або натурою, і що “мають підприємство (виробниче, сільськогосподарське або у сфері обслуговування), але не працюючих" осіб, які протягом звітного періоду тимчасово 
не працювали з будь-якої конкретної причини. Особи, тимчасово непрацюючі через хворобу або травму, свято або відпустку, страйк або локаут, навчальну відпустку, народження дитини, згортання економічної активності, тимчасову дезорганізацію i призупинення роботи у зв'язку з такими причинами, як погана погода, механічна поломка, аварія електромережі, нестача сировини або палива або з іншої причини, повинні відноситися до найнятих робітників за умови, що вони зберігають формальний зв'язок з підприємством. Особи ж, зайняті виробництвом економічних благ і послуг для власного споживання або споживання в домашньому господарстві, повинні відноситися до тих, які працюють на державних підприємствах, якщо таке виробництво забезпечує істотний вклад у загальне споживання домашнього господарства.

Економічно активне населення можна поділити на дві основні групи: збройні сили та економічно активне цивільне населення. Економічно активне населення можна співвіднести із загальним населенням, щоб отримати показник участі в робочій силі, або, щоб точніше, співвіднести з населенням старше віку, встановленого для обліку економічно активного населення. Треба також реалізовувати метод, заснований на розподілі робочого часу, на основі ряду поточних обстежень, які охоплюють показну вибірку звітних періодів протягом року, і в цьому випадку його можна застосувати для оцінки використаного і невикористаного часу протягом року. Оцінки можна виразити в людино-днях, людино-годинах, або перетворити в стандартні повні людино-роки класифікацію обсягів зайнятості і доходів [14].

Для аналізу прихованої неповної зайнятості потрібна інформація про доходи. Задовільні оцінки даних про доходи зазвичай можна отримати у рамках вибіркових обстежень робочої сили і сімейних доходів лише стосовно найнятих робітників, або інших джерел, наприклад, податкових звітів. Потенційна неповна зайнятість, що оцінюється згідно з критерієм низької продуктивності праці, існує у разі, коли індивід працює на підприємстві або в економічній одиниці, де продуктивність ненормально низька.

У різних секторах економіки, зокрема в сільському господарстві, оцінки "надлишків робочої сили" або "резервів робочої сили" можна отримати шляхом порівняння наявних трудових одиниць і фактично використовуваних або необхідних одиниць при різних допущеннях відносно продуктивності [15]. Крім осіб, які в даний момент входять до складу робочої сили, але вклад яких в дохід сімей і національний продукт обмежений в результаті безробіття і повної зайнятості, в багатьох країнах $€$ індивіди, які не належать до робочої сили, але ввійшли б до неї за певних обставин. Такі особи можуть і не шукати активно роботу, наприклад, через відсутність відповідної для них роботи; або ж вони можуть мати фізичні або розумові вади, які можна було б подолати за допомогою навчання або інших коригуючих заходів [13].

Відмовляючись від рамок теоретичних концепцій моделювання 
ринку праці (рівноважної або нерівноважної, тобто $3 n$-ю мірою участі держави), моделюючи підхід до оптимізації системи управління процесом ринку праці, ми дійшли висновку про комплексну інтеграцію вищеописаних складових, які впливають, побічно регенерують компоненти цього процесу, оскільки ринок сам по собі тільки починає формуватися, а ринкові відносини - складатися. Структурно-економічний принцип виводить складність різноманіття взаємозв'язаних соціоекономічних конструкцій. Так, власні і зовнішні ознаки досягнення високого і гнучкого рівня формування економічного агента, відповідного кон'юнктурі ринку праці - це інформація, ідеологія, інвестиції, інновації, інтелект [17].

Не набір економічних агентів, а спосіб їх взаємозв'язку дозволить обчислити функціональне навантаження кожного, що припускає класифікацію макроекономічних явищ (змінних) на внутрішні для цієї системи, ендогенні, і зовнішні, екзогенні. Модельні взаємозв'язки між ними і всередині них характеризують наступні типи співвідношень:

1) зв'язки, що випливають із безпосереднього визначення макроекономічних змінних;

2) умовна формалізація реально існуючих нормативних відносин;

3) технічні залежності, пов’язані 3 умовами функціонування ринку праці і, власне, процесу праці;

4) статичні, відбиваючі наявні тенденції і взаємозалежність змінних;

5) евристичні залежності, що припускають опис поведінки як еко- номічних агентів, так і відгуку на зміну зовнішніх умов внутрішнього стану самої господарської системи. Завдяки взаємозалежності змінних будь-яка цільова ендогенна змінна (наприклад, рівень безробіття) перебуває під впливом усіх сценарних тимчасових. Умисне, внаслідок наміру, або мимовільне, внаслідок управлінського непрофесіоналізму (некомпетентності), викривлення ієрархї наявних структур і змінних веде до неадекватності реакції об’єкта на дію суб'єкта управління. Очевидно, що ринок праці - зовсім не замкнута статична сукупність соціально-економічних концепцій. Як усі процеси, ринок праці має певну протяжність у часі, або має свій "хід часу" і може оцінюватися за мірою інтенсивності зміни ключових параметрів внутрішніх процесів [18].

Простір - час ринку праці конституюється внутрішніми закономірностями, що історично сформувалися під впливом ряду чинників:

Слід тут же зазначити, що і ефективна протидія масовому потенційному, частковому і реальному безробіттю можлива тільки у рамках загальноекономічної антикризової програми. Усі економічні, у тому числі інвестиційні, програми, що розробляються, повинні мати показники попиту на працю, чисельності робочих місць, що зберігаються, або додатково створюваних (реально виробничо і технологічно необхідних або соціально значущих), як нормативи (критеріїв оцінки програм) [19].

Необхідно радикально змінити місце проблем ринку праці в системі пріоритетів державної економічної 


\section{Внутрішні закономірності ринку праці}

\section{Дія суперсистеми. \\ Зовнішнє непереборне середовище}

Розмикає соціальні, господарські, демографічні та ін., що склалися, контури ринку праці і знову формує спосіб функціонування економічних агентів
Соціокультурний генотип.

Внутрішньоструктурне виробництво

Роль історичного зв'язку між поколіннями організаційних схем управління, способів господарювання, схем розподілу трудових та інших ресурсів і т. ін. політики і відповідно перебудувати структуру управління. Суб'єктами антикризового регулювання повинні виступати найвищі органи державної влади і ключові структури Уряду України. Треба переглянути зміст офіційно декларованої активної політики зайнятості, яка розуміється як система заходів сприяння швидкому пошуку роботи або освоєнню працездатним населенням в працездатному віці нових професій. В Україні необхідно спочатку відновити зруйновані і створити нові (ринкові) механізми «виробництва робочих місць, потім стимулювати населення до пошуку, оскільки неможливо шукати те чого немає, що, в пропонованій наявності, фактично не відповідає потребам у працевлаштуванні.

Відділи зайнятості за кордоном, наприклад, в США, мають інформацію про те, хто і де працює, а не тільки про тих безробітних, які звернулися в службу зайнятості (як у нас), що і показує поширення ринку праці як на сферу зайнятості, так і поза нею. Методи підтримки виробництва i систем робочих місць повинні змінитися у бік державних інвестиційних програм і програм державних закупівель у вітчизняних виробників конкретних груп товарів (у першу чергу, високотехнологічних, соціально i екологічно значущих) замість фак- тично безадресних грошових "вливань”, що призводять до “прокрутки” комерційними банками величезних коштів, які не доходять до “адресата” [16].

Для того, щоб підвищити громадський статус працеринкових проблем доцільно привести Конституцію України у відповідність 3 міжнародними уявленнями про соціально-економічні права людини і врахувати багато документів МОП, зокрема, Конвенцію № 122 (1966 р.). Варто істотно відновити і доповнити підзаконну нормативну базу з розширенням і конкретизацією заходів відповідальності державного і районного урядів, державного бюджету і відповідних службових відомств.

Організаційно-управлінський механізм повинен складатися з наступних елементів:

1) структура управління і система координації формування економічних агентів і їх реалізації на ринку праці;

2) правова регламентація взаємодії суб’єктів ринку праці;

3) форми їх діяльності в процесі взаємодії на кожному етапі здійснення працеринкових зв'язків;

4) форми і методи дії (непрямої або прямої) державних, галузевих (що господарських), територіальних 
органів управління на діяльність підприємств, організацій, установ;

5) система інформаційного забезпечення, вивчення і прогнозування попиту на економічних агентів. Різні елементи кожної з підсистем управління пов'язані між собою, утворюючи єдиний відтворювальний процес. Гоніння в ту або іншу сторону відбивають невідповідності, обумовлені розробками в механізмі управління розвитком регіону і трудовими ресурсами, в системі відносин, що будуються на інтересах особистості, з приводу формування, розподілу і використання економічних агентів ринку праці [19]. Через брак належного планування формування економічних агентів, недієві і недостатньо цілеспрямовані економічні важелі і стимули, що посилюється негнучкістю організаційної структури управління, бюрократизацією інституціонального пласта ринку праці.

Економіко-організаційні методи управління ринком мають бути гнучкими з урахуванням кон'юнктури, що постійно міняється, а економічні експерименти відповідно до наукових рекомендацій залежать від прогнозованої реальності і об'єктивних тенденцій розвитку, виходячи з сучасної ситуації в ринковому простоpi, що складається.

Основні (щоправда, важкореалізовані в Україні) вимоги виходу з кризи в трудовій сфері:

а) формування ефективної системи безперервного навчання згідно 3 техніко-технологічними переворотами і ринковою економікою, тобто наявність на ринку праці економічних агентів потрібного і постійно якісно зростаючого рівня кваліфікації; б) можливість формування гідного “середнього класу”;

в) налагодження міжрегіональних зв'язків з питань зайнятості населення, поетапне становлення єдиних систем інформації та розподілу трудових ресурсів;

г) Зняття обмежень в прописці, виїзді за кордон; стимулювання географічної мобільності за допомогою створення ринку вакансій і ринку житла, стимулювання професійної мобільності через сприяння перенавчанню;

д) розширення свободи працівників у виборі місця проживання, роботи, професії, характеру праці і так далі;

е) розробка довгострокової національної політики Україні у галузі міграції фахівців і вчених, захист пріоритетних сфер вітчизняної науки; створення на українському ринку праці адекватних умов для зведення до мінімуму збитку виробництву від вибуття за кордон фахівців, заохочення експорту малокваліфікованої робочої сили з України;

ж) виконання чинного законодавства і створення всеосяжної правової бази нормального функціонування ринку праці; підвищення ролі контрактів трудових договорів у регулюванні умов праці та іï оплати;

з) виховання “любові до праці”, підвищення професіоналізму і ефективного кар'єризму;

i) формування системи соціального захисту тих, хто виїжджає на роботу за кордон, механізму управління процесами виїзду. Досвід роботи громадян України в індустріально розвинених країнах сприяє їх кваліфікованому зростанню, підвищенню 
добробуту їх та їх сімей, що живуть в Україні, впровадженню на батьківщині передових технологій, утворенню спільних підприємств, розвитку ділової активності і підприємництва.

Висновки. Вдосконалення системи економічних механізмів державного регулювання ринку праці має бути спрямоване на забезпечення його ефективного функціонування та розвитку, збалансованості між попитом і пропозицією робочої сили, зростання рівня продуктивної зайнятості трудових ресурсів, оптимального поєднання росту ефективності праці і розширення попиту на робочу силу. Це стане вагомим чинником подальшого соціально-економічного зростання. У ході реалізації засад економічних механізмів державного регулювання ринку праці як на національному, так і на регіональному рівнях усі названі економічні інструменти повинні застосовуватися в єдності та взаємозв’язку.

\section{СПИСОК ВИКОРИСТАНИХ ДЖЕРЕЛ}

1. Ślusarczyk B., Barwińska-Małajowicz A., Czop T. Rynek pracy młodzieży w regionie podkarpackim. Możliwości i bariery, Wyd. AMELIA, Rzeszów 2016. (s. 125).

2. Бараник 3. П. Основні напрями ефективного функціонування ринку праці в контексті інтеграції України до СС // Бюлетень ІПК ДСЗУ. 2006. № 2. C. 10-13.

3. Гриньова В. М. Ринок праці: теоретико-методологічні засади та напрями розвитку: монографія / В. М. Гриньова, В. В. Самойленко. Х.: ВД “ІНЖЕК”, 2007. С. 79.

4. Теоретичні та прикладні засади інвестиційно-інноваційного розвитку економіки та ринку праці в Україні: монографія / за заг. ред. В. Г. Федоренка. К.: ІПК ДСЗУ, 2007. 317 с.

5. Бараник 3. П. Статистика ринку праці: навч. посіб. К .: КНЕУ, 2005. $167 \mathrm{c}$.

6. Богиня Д. П., Куліков Г. Т., Шамоma B. $M$ та інші. Соціально економічний механізм регулювання ринку праці та заробітної плати. Київ: Ін-т економ. НАНУ, 2001. 300 c.

7. Козарь Т. П. Сучасні проблеми державного регулювання ринку праці на регіональному рівні в Україні // Економіка та держава. 2006. № 10. C. 78-80.

8. Акіліна О. В. Актуальні проблеми державного регулювання ринку праці в Україні / О. В. Акіліна // Статистика України. № 1. 2017. C. 90-96.

9. Зуб М. Я. Фактори впливу на розвиток регіонального ринку праці за умов євроінтеграції / М. Я. Зуб // Вісн. Хмельницького нац. ун-ту. № 5. 2009. C. 221-224.

10. Ільӥч Л. М. взаємодія ринків праці та освіти: сутність, характерні риси та модель функціонування / Л. М. Ільїч // Економіка та держава. № 4. 2017. С. 69-74.

11. КурійЛ. О. Використання кількісних i якісних статистичних показників реалізації ефективної міграційної політики / Л. О. Курій / IX Міжнародна наук.-практ. конф. “Складові елементи підвищення економічного потенціалу України за умов глобалізації”. Хмельницький, 2012.

12. Кваша О. С. Ринок праці в Україні: аналіз сучасного стану та перспективи розвитку / О. С. Кваша // Миколаїв. нац. ун-т ім. В. О. Сухомлинського. Вип. 22. 2018. С. $1074-$ 1079.

13. Кір’ян T. Напрями та шляхи подальшого зменшення обсягів безробіття в Україні / Т. Кір'ян, М. Шаповал, 
С. Коваль // Вісн. економічної науки України. № 2. 2013. С. 51-58.

14. Маршавін Ю. М. Регулювання ринку праці України: теорія та практика системного підходу: монографія / Ю. М. Маршавін. К.: Альтерпрес, 2011. 396 c.

15. Kovach Valeriia; Hurkovskyi, Volodymyr (2019). COMPETITION IN LABOR RELATIONS SPHERE. Social and Human Sciences. Polish-Ukrainian scientific journal, 02 (19).

16. Мезенцев К. Зовнішні трудові міграції в контексті зайнятості на ринку праці в Україні / К. Мезенцев, Н. Мезенцева // Вісн. Київського нац. ун-ту імені Тараса Шевченка. № 57. 2010. C. 8-11.

17. Рубежанська В. О. Функції та ключові напрями управління регіональним ринком праці / В. О. Рубежанська // Економіка і суспільство. Вип. 7. 2016. С. 582-589.

18. Федоренко В. Г. Ринок праці та соціально-економічна політика в Україні / В. Г. Федоренко, М. С. Федоренко // Економіка та держава. № 10. 2010. C. 62-64.

19. Федунчик Л. Г. Ринок праці в Україні: проблеми та напрями їх вирішення / Л. Г. Федунчик // Ринок праці та зайнятість населення. № 2. 2016. C. 31-34.

\section{REFERENCES}

1. Ślusarczyk, B., Barwińska-Małajowicz, A., \& Czop T., (2016) Rynek pracy młodzieży w regionie podkarpackim. Możliwości i bariery, Rzeszów: AMELIA [In Polish].

2. Baranyk Z. P. (2006) Osnowni naprjamy efektyonogho funkcionuvannja rynku praci v konteksti integhraciji Ukrajiny do EU [Main directions of efficient functioning of the labor market in the context of Ukraine's integration into the EU] // Kyiv: Bjuletenj IPK DSZU.[in Ukrainian].
3. Ghrynjova V. M. (2007). Rynok praci: teoretyko-metodologhichni zasady ta naprjamy rozoytku [Labor market: theoretical and methodological foundations and directions of development]. Kharkiv: UNZhEK [in Ukrainian].

4. Fedorenko V. G. (Eds.). (2007). Teoretychni ta prykladni zasady investycijno innovacijnogho rozvytku ekonomiky ta rynku praci v Ukrajini: monoghrafija [Theoretical and applied principles of investment-innovative development of the economy and the labor market in Ukraine: monograph]. - Kyiv: IPK DSZU.

5. Baranyk Z. P. (2005). Statystyka rynku praci: Navch. Posib [Labor market statistics: Education handbook]. - Kyiv: KNEU [in Ukrainian].

6. Bohynja D. P., Kulikov G. T., \& Shamota V. M. (2001). Socialjno ekonomichnyj mekhanizm reghuljuvannja rynku praci ta zarobitnoji platy [Socioeconomic mechanism of labor market and wage regulation]. - Kyiv: Inst. ekonom. NANU[in Ukrainian].

7. Kozar T. P. (2006) Suchasni problemy derzhavnogho reghuljuvannja rynku praci na reghionaljnomu rioni v Ukrajini [Socio-economic mechanism of labor market and wage regulation]. Ekonomika ta derzhava - Economics and State, 10, 78-80 [in Ukrainian].

8. Akilina O. V. (2017). Aktualjni problemy derzhavnogho reghuljuvannja rynku praci v Ukrajini [Actual problems of state regulation of the labor market in Ukraine]. Statystyka Ukrajiny - Statistics of Ukraine, 1, 90-96 [in Ukrainian].

9. Zub M. Ia. (2009) Faktory vplyvu na rozvytok reghionaljnogho rynku praci za umov jevrointeghraciji [Factors influencing the development of the regional labor market in the context of European integration]. Visnyk Khmeljnycjkogho nacionaljnogho universytetu - Bulletin of the Khmelnyt- 
sky National University, 5, 221-224 [in Ukrainian].

10. Iliich L. M. (2017). Vzajemodija rynkiv praci ta osvity: sutnistj, kharakterni rysy ta modelj funcionuvannja [Interaction of labor markets and education: essence, characteristics and model of functioning]. Ekonomika ta derzhava Economics and State, 4, 69-74 [in Ukrainian].

11. Kurii L. O. (2012) Vykorystannja kiljkisnykh i jakisnykh statystychnykh pokaznykiv realizaciji efektyvnoji mighracijnoji polityky [Use of quantitative and qualitative statistical indicators for the implementation of effective migration policy]. Proceedings from: IX Mizhnarodna naukovopraktychna konferencija Skladovi elementy pidoyshhennja ekonomichnogho potencialu Ukrajiny za umov ghlobalizaciji [IX International Scientific and Practical Conference "Components of enhancing the economic potential of Ukraine in the context of globalization"]. - Khmeljnycjkyj [in Ukrainian].

12. Kvasha O. S. (2018). Rynok praci v Ukrajini: analiz suchasnogho stanu ta perspektyoy rozoytku [The labor market in Ukraine: analysis of the current state and prospects for development]. Mykolajivsjkyj nacionaljnyj universytet imeni V. O. Sukhomlynsjkogho - Sukhomlynskyi Mykolaiv National University, 22, 1074-1079 [in Ukrainian].

13. Kirian T., Shapoval M., Koval S. (2013). Naprjamy ta shljakhy podaljshogho zmenshennja obsjaghiv bezrobittja v Ukrajini [Directions and Ways to Further Reduce Unemployment in Ukraine]. Visnyk ekonomichnoji nauky Ukrajiny - Bulletin of the economic science of Ukraine, 2, 51-58 [in Ukrainian].

14. Marshavin Ju. M. (2011). Reghuljuvannja rynku praci Ukrajiny: teorija ta praktyka systemnogho pidkhodu: monoghrafija [The Theory and Practice of a Systematic Approach: Monograph]. Kyiv: Alterpres, 2011 [in Ukrainian].

15. Kovach Valeriia; Hurkovskyi Volodymyr (2019). COMPETITION IN LABOR RELATIONS SPHERE. Social and Human Sciences. PolishUkrainian scientific journal, 02 (19) [in English].

16. Mezencev K., Mezenceva N. (2016). Zovnishni trudovi mighraciji $\mathrm{v}$ konteksti zajnjatosti na rynku praci $\mathrm{v}$ Ukrajini [External labor migration in the context of employment in the labor market in Ukraine]. Visnyk Kyjizsjkogho nacionaljnogho universytetu imeni Tarasa Shevchenka - Bulletin of the Taras Shevchenko Kyiv National University, 57, 8-11[in Ukrainian].

17. Rubezhansjka V. O. (2016) Funkciji ta kljuchovi naprjamy upravlinnja reghionaljnym rynkom praci [Functions and key areas of management of the regional labor market]. Ekonomika i suspiljstvo - Ecomomics and Society, 7 , 582-589 [in Ukrainian].

18. Fedorenko V., Fedorenko M. S. (2010). Rynok praci ta socialjno-ekonomichna polityka v Ukrajini [Labor market and socio-economic policy in Ukraine] // Ekonomika ta derzhava - Economics and State, 10, $62-64$ [in Ukrainian].

19. Fedunchyk L. (2016). Rynok praci v Ukrajini: problemy ta naprjamy jikh vyrishennja [The labor market in Ukraine: problems and directions of their solution]. Rynok praci ta zajnjatistj naselennja - Labour market and Employment, 2, 31-34 [in Ukrainian]. 